\title{
Asymptomatic giant mediastinal mass: a rare case of thymolipoma*,**
}

\author{
Massa mediastinal gigante assintomática: um raro caso de timolipoma \\ Omar Moté Abou Mourad, Filipe Moreira de Andrade, \\ Pedro Abrahão, Andréa Monnerat, Luiz Felippe Judice
}

\begin{abstract}
Thymolipoma is a very rare benign neoplasm of the thymus. We present the case of a 42-year-old male with a massive mediastinal tumor discovered on a chest $\mathrm{X}$-ray after a motorcycle accident. The patient had no complaints, and his physical examination was unremarkable. Chest CT scans revealed a lipomatous mass containing areas of soft tissue density. The patient was submitted to median sternotomy expanded to left anterolateral thoracotomy, resulting in the complete excision of the tumor. The pathological diagnosis was thymolipoma. Thymolipoma usually attains enormous dimensions by the time of diagnosis, and the occasional symptoms are related to compression of adjacent structures. Surgical resection is the treatment of choice and offers the only possibility of cure. The airway deserves special care during anesthesia induction.
\end{abstract}

Keywords: Thymus neoplasms; Mediastinal neoplasms; Thymectomy; Lipoma.

\section{Resumo}

Timolipoma é uma rara neoplasia benigna do timo. Apresentamos o caso de um paciente do sexo masculino de 42 anos de idade com um volumoso tumor mediastinal, descoberto após a realização de radiografia de tórax devido a um acidente motociclístico. Não apresentava queixas e ao exame físico não havia particularidades. A TC de tórax revelava uma massa lipomatosa entremeada por tecido com densidade de partes moles. 0 paciente foi submetido a uma esternotomia mediana com extensão para toracotomia ântero-lateral esquerda, permitindo a exérese completa do tumor. 0 diagnóstico histopatológico foi de timolipoma. 0 timolipoma geralmente atinge grandes dimensões na época do diagnóstico, sendo os ocasionais sintomas relacionados à compressão de estruturas adjacentes. A ressecção cirúrgica é o tratamento de escolha e a única possibilidade de cura. A via aérea merece atenção especial durante a indução anestésica.

Descritores: Neoplasias do timo; Neoplasias do mediastino; Timectomia; Lipoma.

\section{Introduction}

Thymolipoma is a rare, benign neoplasm of the thymus composed of mature adipose and thymic tissue. Less than two hundred cases have been described in the literature. Although rare, the diagnosis of thymolipoma should be considered in the occurrence of an anterior mediastinal mass with fat density, especially if interspersed with strands of soft tissue attenuation on CT scans. ${ }^{(1)}$

\section{Case report}

A 42-year-old male was admitted to our hospital because of an abnormal chest X-ray obtained at another health care unit after a motorcycle crash with no victims. The patient had no complaints, and the only finding of interest in the physical examination was the complete absence of vesicular breath sounds on the left. The laboratory findings were not remarkable.

\footnotetext{
* Study carried out in the Department of Surgery, Division of Thoracic Surgery, Hospital Universitário Antonio Pedro - HUAP, Antonio Pedro University Hospital - of the Universidade Federal Fluminense - UFF, Fluminense Federal University - School of Medicine, Niterói, Brazil.

Correspondence to: Luiz Felippe Judice. Rua da Conceição, 188, Sala 903-B, Centro, CEP 24020-083, Niterói, RJ, Brasil.

Tel 5521 2629-9000. E-mail: Ifjudice@urbi.com.br

Financial support: None.

Submitted: 18 June 2009. Accepted, after review: 28 July 2009.

** A versão completa em português deste artigo está disponível em www.jornaldepneumologia.com.br
} 

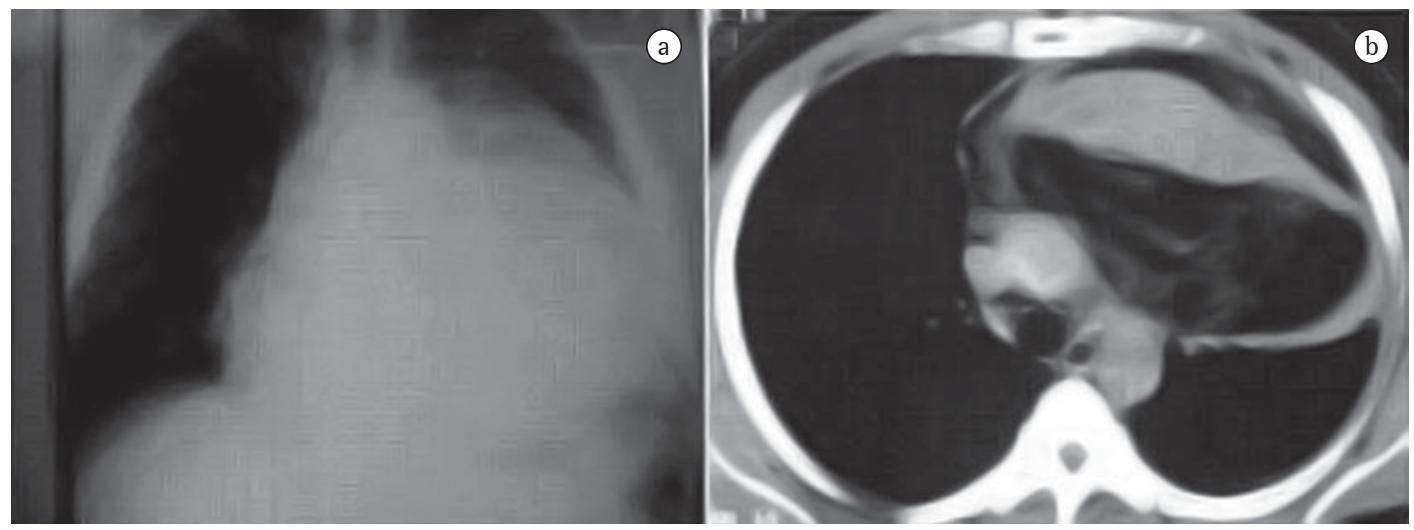

Figure 1 - a) Chest X-ray revealing opacity in the mediastinum and in the left hemithorax, resembling cardiomegaly. b) CT scan of the chest showing a large anterior mediastinal mass projecting to the left hemithorax; fat density interspersed with areas of soft tissue density.

An anteroposterior X-ray of the chest revealed an opacity occupying the mediastinum and the left hemithorax (Figure 1). A chest $\mathrm{CT}$ scan revealed a large mass occupying the anterosuperior mediastinum and extending into the left hemithorax, from the diaphragm to the apex, displacing the lung posteriorly $(22 \times 19 \times 17 \mathrm{~cm})$. The mass was comprised of areas of fat density interspersed with areas of soft tissue density, causing lung collapse and discrete heart compression (Figure 1). The mass draped around the heart and the great vessels, especially around the left brachiocephalic vein and the ascending aorta. Magnetic resonance imaging (MRI) scans showed whorls of high signal intensity intermixed with areas of intermediate intensity on T2-weighted images (Figure 2), as well as a projection of the mass between the aortic arch and the pulmonary trunk. There was no clear plane among the aortic arch, the left brachiocephalic vein and the tumor, but there was no invasion of these structures on the MRI.

The patient was scheduled for surgical resection. Because of the partial obstruction in the left main bronchus, the anesthesiology team decided to intubate the patient, allowing spontaneous breathing after inhalational induction with the use of a selective tube. Neuromuscular blockade was then instituted.

We performed partial sternotomy accompanied by left thoracotomy through the fifth intercostal space. The tumor was anterolateral to the pericardium, displacing the left lung posteriorly and the pericardium medially. There was no invasion of neighboring structures. The tumor was relatively easily freed by blunt and sharp dissection. Care was taken to identify and preserve the left phrenic nerve. The pleural cavity was drained using two chest tubes.

Macroscopically, the resected tumor was encapsulated by a soft smooth elastic surface and composed of a yellowish tissue. The histopathological diagnosis revealed a benign thymolipoma consisting of mature fatty tissue and hyperplastic thymic structures with Hassall's corpuscles (Figure 3).

The postoperative period was uneventful, and the patient was discharged on the fifth postoperative day.

\section{Discussion}

The first reported case of a lipoma of the thymus was published by Lange in $1916 .^{(2)}$ Much

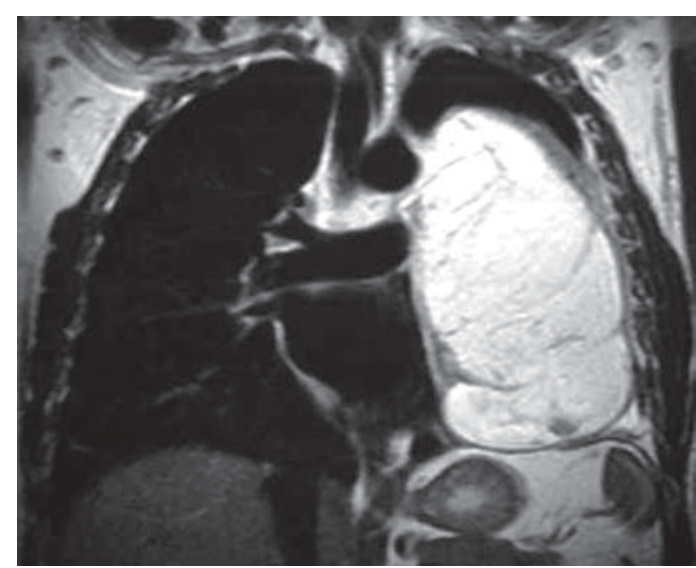

Figure 2 - Magnetic resonance imaging scan of the chest showing the mass projecting between the aortic arch and the right pulmonary artery. 

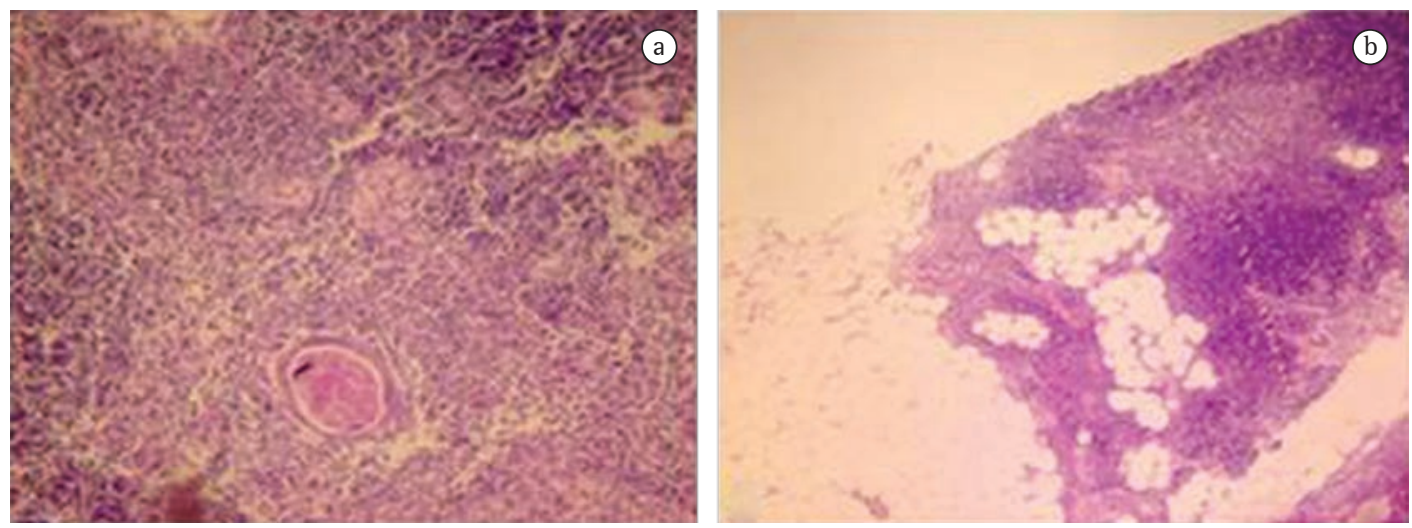

Figure 3 - a) Photomicrograph of the specimen revealing a Hassall's corpuscle surrounded by normal thymic tissue (H\&E; magnification, $\times 100)$. b) Mature adipose tissue interspersed with microscopically normal thymus tissue showing lymphocytes, which are features consistent with thymolipoma (H\&E; magnification, $\times 100$ ).

later, in 1948. Hall introduced the term thymolipoma into the literature. ${ }^{(2)}$

Thymolipoma is an uncommon benign neoplasm that accounts for 2-9\% of thymic tumors. ${ }^{(3)}$ There is no gender difference in its incidence, and the onset can occur at any age. ${ }^{(4)}$ It is also known as lipoma of the thymus, lipothymoma and thymolipomatous hamartoma, although we believe that thymolipoma is the most appropriate and clear designation.

Although the cause of thymolipoma is unclear, the most widely accepted theory of pathogenesis is the replacement of the thymus by mature adipose tissue, although four additional theories have been proposed: first, thymolipoma would be a lipoma consisting of thymic fat with involution of the thymic gland; second, the "involuting hyperplasia theory" proposes that a diffuse true thymic hyperplasia is replaced by fatty tissue in the same way in which it occurs in the normal thymus, but on a larger scale; third, the "mixed tumor theory" defends a mixed neoplasm of mesenchymal and endodermal origin, in which islands of noninvoluted thymic tissue are found in fatty tissue; and fourth, the "involuting thymoma theory", according to which fatty degeneration of the thymoma occurs in a similar way as does fatty replacement during the aging process. ${ }^{(5)}$

Thymolipomas usually grow slowly and can reach large sizes before the diagnosis. Images on X-rays can resemble cardiomegaly. ${ }^{(6)}$ When the patient experiences symptoms, they are usually related to compression of adjacent structures, such as the heart, the great vessels, the lungs or the bronchi. ${ }^{(7)}$ This benign neoplasm can be asso- ciated with some autoimmune disorders, such as myasthenia gravis, systemic lupus erythematosus, hypogammaglobulinemia, Graves' disease and red cell aplasia. ${ }^{(8-10)}$

Characteristic CT findings involve fatty tissue containing soft tissue streaks that probably represent islands of normal thymic components. ${ }^{(11)}$ Fat density on CT scans, however, can also indicate lipoma, liposarcoma, teratoma, prominent epicardial fat pad or congenital diaphragmatic hernias. ${ }^{(1)}$ In general, MRI scans show areas of high signal intensity intermingled with areas of intermediate intensity on T2-weighted images, and the adipose tissue of the tumor appears isointense in $\mathrm{T} 1$-weighted images. ${ }^{(12)}$ Although the diagnosis is strongly suggested by imaging studies that demonstrate fat and soft tissue within the tumor without the invasion of neighboring structures, it is not possible to make an exact diagnosis or even to differentiate benign from malignant neoplasms. ${ }^{(13,14)}$ Although biopsy can be technically feasible, it is not indicated in these cases, because the mass must be surgically addressed and, if possible, completely excised.

The only curative treatment is surgical resection of the tumor, which can be accomplished via sternotomy, anterolateral thoracotomy, clamshell incision or sternotomy accompanied by anterolateral thoracotomy (hemiclamshell incision). The choice must be individualized for each anatomical presentation of the neoplasm. ${ }^{(4,8)}$ Some groups have reported a thoracoscopic approach, but we disagree with this method because it would nevertheless be necessary to perform a relatively large thoracotomy in order to remove the mass from within the thorax. 


\section{References}

1. Faerber EN, Balsara RK, Schidlow DV, Marmon LM, Zaeri N. Thymolipoma: computed tomographic appearances. Pediatr Radiol. 1990;20(3):196-7.

2. Hall GF. A case of thymolipoma with observations on a possible relationship to intrathoracic lipomata. $\mathrm{Br} \mathrm{J}$ Surg. 1949;36(143):321-4.

3. Halkos ME, Symbas JD, Symbas PN. Acute respiratory distress caused by massive thymolipoma. South Med J. 2004;97(11):1123-5.

4. Moran CA, Rosado-de-Christenson M, Suster S. Thymolipoma: clinicopathologic review of 33 cases. Mod Pathol. 1995;8(7):741-4.

5. Toyama T, Mizuno T, Masaoka A, Shibata K, Yamakawa Y, Niwa H, et al. Pathogenesis of thymolipoma: report of three cases. Surg Today. 1995;25(1):86-8.

6. Gamanagatti S, Sharma R, Hatimota P, Guleria R, Arvind S. Giant thymolipoma. AJR Am J Roentgenol. 2005;185(1):283-4.

7. Ceran S, Tulek B, Sunam G, Suerdem M. Respiratory failure caused by giant thymolipoma. Ann Thorac Surg. 2008;86(2):661-3.
8. Rosado-de-Christenson ML, Pugatch RD, Moran CA, Galobardes J. Wang Y, Sun Y, et al. Diagnosis, treatment and prognosis of thymoma: an analysis of 116 cases. Chin Med J (Engl). 2003;116(8):1187-90.

9. Wang Y, Sun Y, Zhang J, Zhou N, Liu Y, LiY, et al. Diagnosis, treatment and prognosis of thymoma: an analysis of 116 cases. Chin Med J. 2003;116(8):1187-90.

10. Roque C, Rodríguez P, Quintero C, Santana N, Hussein M, Freixinet J. Giant thymolipoma [Article in Spanish]. Arch Bronconeumol. 2005;41(7):402-3.

11. Shields TW, Robinson PG. Mesenchymal tumors of the mediastinum. In: Shields TW, LoCicero J, Ponn RB, editors. General Thoracic Surgery, Vol. 2. 5ed. Philadelphia: Lippincott Williams \& Wilkins; 2000. p. 2357-423.

12. Shirkhoda A, Chasen MH, Eftekhari F, Goldman AM, Decaro LF. MR imaging of mediastinal thymolipoma. J Comput Assist Tomogr. 1987;11(2):364-5.

13. Saad Jr R, Dorgan Neto V, Gonçalves R, Botter M, Siqueira LC. Mediastinal liposarcoma: a case report. J Bras Pneumol. 2008;34(1):55-8.

14. Mase T, Kawawaki N, Narumiya C, Aoyama T, Kato S, Nagata Y. Primary liposarcoma of the mediastinum. Jpn J Thorac Cardiovasc Surg. 2002;50(6):252-5.

\section{About the authors}

\section{Omar Moté Abou Mourad}

Assistant Professor of Thoracic Surgery. Hospital Universitário Antonio Pedro - HUAP, Antonio Pedro University Hospital - of the Universidade Federal Fluminense - UFF, Fluminense Federal University - School of Medicine, Niterói, Brazil.

\section{Filipe Moreira de Andrade}

Resident in Thoracic Surgery. Hospital Universitário Antonio Pedro - HUAP, Antonio Pedro University Hospital - of the Universidade Federal Fluminense - UFF, Fluminense Federal University - School of Medicine, Niterói, Brazil.

\section{Pedro Abrahão}

Resident in Thoracic Surgery. Hospital Universitário Antonio Pedro - HUAP, Antonio Pedro University Hospital - of the Universidade Federal Fluminense - UFF, Fluminense Federal University - School of Medicine, Niterói, Brazil.

\section{Andréa Monnerat}

Assistant Professor of Pathology. Hospital Universitário Antonio Pedro - HUAP, Antonio Pedro University Hospital - of the Universidade Federal Fluminense - UFF, Fluminense Federal University - School of Medicine, Niterói, Brazil.

\section{Luiz Felippe Judice}

Full Professor of Thoracic Surgery. Hospital Universitário Antonio Pedro - HUAP, Antonio Pedro University Hospital - of the Universidade Federal Fluminense - UFF, Fluminense Federal University - School of Medicine, Niterói, Brazil. 